\title{
DAMPAK ERA NEW NORMAL TERHADAP PEKERJA SEKTOR INFORMAL
}

\author{
Lilis Sri Sulistiani \\ Administrasi Publik Fisip Unsoed Purwokerto \\ lilis.sulistiani@unsoed.ac.id \\ Malang, Indonesia
}

\begin{abstract}
The impact of the Covid-19 pandemic on workers in the informal sector is a decrease in income and production capacity, as well as a reduction in labor. This study aims to analyze the impact of implementing the new normal era on informal sector workers and formulate strategies for surviving the pandemic.

The research method used in this paper is descriptive qualitative method by applying literature study.

The results of the study show that the implementation of the first new normal era has an impact on business situations that are volatile, uncertain, complicated and confusing. Second, the impact of the pandemic on business people has resulted in limited resources. Third, changes in consumer behavior who prefer online shopping. So that the economic recovery of informal sector workers in the new normal era requires various strategies, namely: the existence of occupational health and safety insurance, the ability to work together, the ability to adapt services to changes in consumer behavior, to have innovation and creativity in running a business.
\end{abstract}

Keywords: Informal Sector Workers; Informal Sector; New Normal Era

\begin{abstract}
Abstrak
Dampak pandemi Covid-19 terhadap pekerja di sektor informal adalah penurunan pendapatan dan kapasitas produksi, serta pengurangan tenaga kerja. Studi ini bertujuan untuk menganalisis dampak penerapan era normal baru pada pekerja sektor informal dan merumuskan strategi agar dapat bertahan di tengah pandemi. Metode penelitian yang digunakan dalam paper ini adalah metode kualitatif deskrptif dengan menerapkan studi kepustakaan. Hasil kajian menunjukkan bahwa penerapan era normal baru pertama, berdampak pada situasi bisnis yang bergejolak, ketidakpastian, rumit dan membingungkan. Kedua, dampak pandemi pada pelaku bisnis menyebabkan terjadinya keterbatasan sumber daya. Ketiga, perubahan perilaku konsumen yang lebih memilih belanja secara online. Sehingga pemulihan perekonomian pekerja sektor informal di era normal baru memerlukan berbagai strategi, yaitu: adanya jaminan kesehatan dan keselamatan kerja, kemampuan bekerjasama, kemampuan adaptasi pelayanan terhadap perubahan perilaku konsumen , memiliki inovasi dan kreativitas dalam menjalankan bisnis..
\end{abstract}

Kata Kunci: Era Normal Baru; Pekerja Sektor Informal; Sektor Informal

Open Access at:http://ojs.uho.ac.id/index.php/PUBLICUHO/index

Journal Publicuho is licensed under a Creative Commons Attribution 4.0 International License. 


\section{Journal Publicuho}

ISSN2621-1351 (online), ISSN 2685-0729 (print)

Volume 4 Number 2 (May-July), (2021)pp. 248-258

Accredited SINTA SK.NOMOR 28/E/KPT/2019

Open Access at:http://ojs.uho.ac.id/index.php/PUBLICUHO/index

DOI: 10.35817/jpu.v4i2.17705

\section{PENDAHULUAN}

Pemerintah Indonesia menerapkan kebijakan pembatasan sosial, pembatasan fisik, bekerja dari rumah dan sekolah dari rumah setelah merebaknya pandemi Covid-19. Langkah pembatasan tersebut dilakukan untuk mencegah penyebaran virus yang membahayakan kesehatan masyarakat.

Dampak dari kebijakan tersebut adalah terbatasnya kegiatan ekonomi sehingga menimbulkan goncangan di berbagai sektor. Pembatasan sosial berimbas pada berubahnya pola kerja di sektor formal, dimana perusahaan harus mematuhi protokol kesehatan dengan mengatur jumlah pekerja sesuai dengan jarak aman. Hal ini berdampak pada menurunnya tingkat produktivitas perusahaan. Kondisi ini diperparah dengan menurunnya daya beli masyarakat akibat penurunan tingkat pendapatan keluarga yang berakibat pada menurunnya tingkat penjualan perusahaan. Sehingga perusahaan tidak mampu untuk membayar upah dan berujung pada pengurangan tenaga kerja.

Pengurangan tenaga kerja di berbagai sektor tidak dapat dihindarkan. Selain sebagian besar dirumahkan, sebagian lainnya mengalami pemutusan hubungan kerja. Berdasarkan data dari Kementeriaan Tenaga Kerja hingga bulan Juli 2020, jumlah tenaga kerja yang mengalami pemutusan hubungan kerja baik formal maupun informal ada 2,1 juta orang. Pekerja formal yang dirumahkan 1,1 juta dan yang menerima pemutusan hubungan kerja 380.000 orang. Sedangkan di sektor informal yang terdampak Covid-19 mencapai 630.000 orang. Angka tersebut adalah jumlah yang sudah diverifikasi oleh BPJS, sedangkan data keseluruhan ada 3,5 juta.(Yazid, 2020)

Hasil kajian SMERU mengenai dampak pandemic Covid-19 mempresentasikan bahwa ada enam sector terkena dampak pandemic Covid-19, dimana ke enam sector itu merupakan lapangan usaha yang memiliki proporsi tenaga kerja relatif besar yaitu sekitar 70,5 juta orang. Data selengkapnya sebagai berikut:

Tabel 1. Laju Pertumbuhan Produk Domestik Bruto dan Proporsi Tenaga Kerja di Enam Sektor

\begin{tabular}{llcc}
\hline No. & \multicolumn{1}{l}{ Enam Sektor Lapangan Usaha } & $\begin{array}{r}\text { Pertumbuhan PDB } \\
\text { Q4 2019-Q1 2020 }\end{array}$ & $\begin{array}{c}\text { Proporsi Tenaga Kerja } \\
(\%)\end{array}$ \\
\hline 1. & Industri Pengolahan & $-1,7$ & 14,88 \\
\hline 2. & Konstruksi & $-6,92$ & 6,65 \\
\hline 3. & Perdagangan & $-1,38$ & 19,00 \\
\hline 4. & Transportasi dan Pergudangan & $-6,38$ & 4,36 \\
\hline 5. & $\begin{array}{l}\text { Penyedia Akomodasi, makanan dan } \\
\text { minuman }\end{array}$ & $-3,54$ & 6,69 \\
\hline 6. & Jasa lainnya & $-1,19$ & 4,09 \\
\hline & $\quad$ Sumber : (BADAN PUSAT STATISTIK, 2020)
\end{tabular}

Data hasil kajian Lembaga Riset SMERU memperlihatkan bahwa sebagain besar tenaga kerja di lapangan usaha yang terdampak krisis ekonomi akibat pandemic Covid-19, berasal 
dari sektor yang memiliki proporsi jumlah tenaga kerja cukup banyak. Yaitu pada sektor perdagangan, industri pengolahan dan penyedia akomodasi, makanan dan minuman.

Ketiga sektor tersebut merupakan sektor yang memiliki jumlah tenaga kerja informal cukup tinggi. Hasil survey yang dilakukan oleh Badan Pusat Statistik menggambarkan bahwa di setiap sektor formal di dalamnya selalu ada tenaga kerja informal. Data selengkapnya status tenaga kerja di enam sektor sebagai berikut :

Tabel 2. Proporsi Tenaga Kerja di Enam Sektor Berdasarkan Status Formal/Informal (\%)

\begin{tabular}{llccc}
\hline No. & Jenis Lapangan Usaha & Jumlah & \multicolumn{2}{c}{ Status Tenaga Kerja } \\
\hline & & & Formal & Informal \\
\hline 1. & Industri Pengolahan & 69.086 .124 & 64,77 & 35,23 \\
\hline 2. & Perdagangan & 24.378 .151 & 33,54 & 66,46 \\
\hline 3. & $\begin{array}{l}\text { Penyedia Akomodasi, Makanan dan } \\
\text { minuman }\end{array}$ & 8.584 .428 & 31,83 & 68,17 \\
\hline 4. & Konstruksi & 8.525 .367 & 51,35 & 48,65 \\
\hline 5. & Jasa Lainnya & 6.369 .510 & 54,39 & 45,61 \\
\hline 6. & Transportasi dan Pergudangan & 5.590 .772 & 40,68 & 59,32 \\
\hline
\end{tabular}

Sumber : (Rahman et al., 2020)

Dari ke enam sektor tersebut, sektor konstruksi, industri pengolahan, dan jasa lainnya di dominasi oleh pekerja formal, sedangkan sector penyedia akomodasi, makanan dan minuman, transportasi pergudangan, dan perdagangan didominasi oleh pekerja sektor informal.

Pekerja sektor informal merupakan kegiatan yang erat kaitannya dengan sektor formal. Kehadirannya selalu memanfaatkan keberadaan sektor formal, di mana sektor formal berada maka pelaku sektor informal akan muncul. Keberadaannya sangat mudah dijumpai di dekat pusat keramaian. Sedangka sarana yang digunakan adalah hamparan di lantai, meja, gerobak, pikulan, dan lain sebagainya.( Yustika, 2011)

Pembatasan kegiatan di sektor formal melalui bekerja dari rumah dan pengurangan jam operasional menjadikan kegiatan sektor informal kehilangan pelanggannya. Kondisi ini berakibat pada penurunan tingkat penjualan bagi pekerja sektor informal. Dampak berikutnya adalah penurunan tingkat pendapatan keluarga yang akan berakibat pada menurunnya daya beli.

Hasil kajian Amnesty Internasional Indonesia, pandemi Covid-19 berdampak pada sektor formal dengan pemotongan upah dan pemutusan hubungan kerja karena pemilik usaha tidak mampu membayar upah akibat penurunan pendapatan. Sedangkan pekerja sektor informal yang sebagian besar tidak tercakup dalam sistem jaminan sosial kehilangan pelanggannya akibat berkurangnya sektor formal.(Dampaknya et al., n.d.) Sejalan dengan kajian Amnesty Internasional Indonesia, ILO melalui kajiannya menemukan bahwa sebagian besar pekerja sektor informal tidak memiliki jaminan sosial, kecelakaan kerja dan kematian seperti pekerja formal. Sehingga dalam kondisi tanpa pendapatan, tidak 


\section{Journal Publicuho}

ISSN2621-1351 (online), ISSN 2685-0729 (print)

Volume 4 Number 2 (May-July), (2021)pp. 248-258

Accredited SINTA SK.NOMOR 28/E/KPT/2019

Open Access at:http://ojs.uho.ac.id/index.php/PUBLICUHO/index

DOI: 10.35817/jpu.v4i2.17705

ada pilihan lain kecuali tetap bekerja walaupun resiko kemungkinan tertular lebih tinggi. (ILO, 2020).

Perkembangan pandemic Covid-19 yang semakin mengkhawatirkan dan berdampak pada melemahnya pertumbuhan ekonomi yang cukup tajam hingga 2,97 persen di kuartal 1, mendorong pemerintah untuk segera membuka aktivitas perekonomian kembali. Pemerintah mengambil langkah untuk memberlakukan kenormalan baru dengan berbagai pertimbangan.

Kementrian Koordinator Perekonomian memaparkan beberapa pertimbangan yang mendasari pemerintah memberlakukan tatanan kenormalan baru, adalah sebagai berikut:

a. Dampak pandemi terhadap pekerja sektor informal yang jumlahnya antara 50 - 70 juta pekerja.

b. Meningkatnya jumlah pengangguran berdampak pada menurunnya tingkat konsumsl.

c. Bertambahnya jumlah masyarakat kategori miskin.

d. Pekerja sektor informal yang tidak memiliki jaminan sosial, jumlahnya lebih besar dibandingkan pekerja sektor formal.

e. Negara tidak akan mampu memberikan bantuan secara terus menerus (Novika, 2020)

Berdasarkan latar belakang tersebut, kajian ini bertujuan untuk menganalisis bagaimana tantangan yang dihadapi pekerja sektor informal di era normal baru dan merumuskan rekomendasi strategi yang harus dijalankan agar dapat bertahan di masa yang penuh dengan ketidakpastian.

\section{METODOLOGI}

Metode penelitan yang digunakan adalah kualitatif deskriptif dengan menerapkan studi kepustakaan, yang tujuan utamanya adalah mengembangkan aspek teoritis maupun aspek manfaat praktis. Menurut Zed (2008:3) studi kepustakaan adalah serangkaian kegiatan yang berkenaan dengan metode pengumpulan data pustaka, membaca dan mencatat serta mengolah bahan penelitian.

Menurut Sanusi (2016:32), penelitian kepustakaan adalah penelitian yang dilakukan dengan menganalisis sumber data yang berasal dari karya atau hasil penelitian ilmiah. Kajian pustaka ini bertujuan untuk menelaah permasalah pada sektor informal yang saat ini terdampak pandemi.

Sumber tulisan sebagai sumber data primer adalah publikasi ilmiah berkala diantaranya jurnal yang merupakan hasil penelitian. Sedangkan sumber data sekunder adalah berbagai sumber tulisan yaitu book chapter, karya ilmiah yang diterbitkan pada jurnal, buku literatur, laporan hasil survey dan surat kabar elektronik.

Untuk menjawab permasalahan dan tujuan kajian, dilakukan melalui proses menghimpun sumber primer dan sekunder, kategorisasi sumber pustaka, pengambilan data sumber 
pustaka, menampilkan data, mengabstraksi data sebagai fakta dan menganalisis data.( Darmalaksana, 2020).

\section{HASIL DAN PEMBAHASAN}

\section{Konsep Sektor Informal}

Pemerintahan di negara-negara berkembang mengalami banyak kesulitan untuk menerapkan anjuran badan kesehatan dunia dalam mencegah penularan Covid-19. Salah satu kesulitan yang dialami Indonesia untuk menerapkan pembatasan dan penutupan wilayah secara total karena pemerintah tidak mampu menjamin kebutuhan logistik masyarakat secara penuh. Sehingga permasalahan kesehatan akan bertentangan dengan pemenuhan kebutuhan ekonomi. Di satu sisi pemerintah berkewajiban melindungi masyarakat dari penularan, tetapi di sisi lain masyarakat terpaksa harus beraktivitas di tengah pandemi untuk memenuhi kebutuhan hidupnya.

Salah satu kelompok masyarakat yang rentan terhadap guncangan ekonomi adalah pekerja sektor informal. Sektor informal memiliki karakteristik unik diantaranya adalah bervariasinya bidang kegiatan produksi barang dan jasa, berskala kecil, unit produksi milik perorangan atau keluarga, menggunakan tenaga kerja (padat karya), dan teknologi yang dipakai relatif sederhana. (Todaro, 2008)

Perdebatan konsep sektor informal telah terjadi sejak pertama kali konsep ini diperkenalkan. Perdebatan muncul berkisar pada bagaimana mengukur volume, karena sebagian besar sektor informal tidak ditemukan dan tidak dilaporkan secara resmi. Namun sektor informal telah berkontribusi dalam menyediakan lapangan kerja.(Bairagya, 2014)

Pronk mengungkapkan bahwa sektor informal merupakan konsep yang penting dalam diskusi kemiskinan di kota. Walaupun definisi dan kriteria yang membedakan konsep sektor formal dan informal banyak dijumpai pada berbagai literature, ternyata tidak mudah untuk mendefinisikan sektor informal. Lebih lanjut Pronk, menjelaskan bahwa sektor informal merupakan istilah generik yang meliputi beraneka macam kegiatan dalam produksi dan jasa yang tidak dapat dilepaskan dari sektor formal. (Pronk, 1993).

Istilah sektor informal menurut Kamus Besar Bahasia Indonesia sering diidentikan dengan usaha tidak resmi; lapangan pekerjaan yang dikelola sendiri oleh pencari kerja atau sering pula disebut dengan wiraswasta. Sektor informal memiliki unit usaha kecil yg melakukan kegiatan produksi dan/atau distribusi barang dan jasa untuk menciptakan lapangan kerja dan penghasilan bagi mereka yg terlibat unit tersebut. Kegiatan sektor informal bekerja dengan keterbatasan, baik modal, fisik, tenaga, maupun keahlian. (KBBI, 2016).

Sedangkan menurut Cano dan Ubina (2015), sektor informal adalah pasar tenaga kerja di negara berkembang, menampung tenaga kerja yang gagal masuk ke pasaran sektor 


\section{Journal Publicuho}

ISSN2621-1351 (online), ISSN 2685-0729 (print)

Volume 4 Number 2 (May-July), (2021)pp. 248-258

Accredited SINTA SK.NOMOR 28/E/KPT/2019

Open Access at:http://ojs.uho.ac.id/index.php/PUBLICUHO/index

DOI: 10.35817/jpu.v4i2.17705

formal. Biasanya dicirikan dengan tenaga kerja muda yang tidak memiliki keterampilan, upah rendah dan tidak menerima jaminan sosial seperti pekerja di sektor formal. Cano dan Ubina menjelaskan lebih lanjut bahwa perbedaan tenaga kerja sektor formal dan informal dapat dilihat terutama dari tunjangan kesehatan dan jaminan sosial. Pekerja sektor formal adalah pekerja yang menerima upah dan tunjangan kesehatan sesuai dengan peraturan dan undang-undang. Sedangkan pekerja sektor informal menerima upah tetapi tidak menerima tunjangan kesehatan dan jaminan sosial.

Selain bekerja sebagai pekerja mandiri yang tidak memiliki institusi, pekerja sektor informal dapat dibedakan berdasarkan sumber penghasilan. Seperti yang dikemukakan oleh Chen, (2012) yang mengidentifikasi bahwa dalam konteks informal pekerja terdiri dari dua, yaitu pemilik dan pekerja. Lebih jelasnya dapat dilihat pada kategori sebagai berikut:

a. Wirausaha yang meliputi pemberi kerja di perusahaan informal, pekerja mandiri di perusahaan informal, dan pekerja keluarga yang berkontribusi pada perusahaan informal

b. Pekerja upahan, yaitu karyawan perusahaan informal, pekerja lepas, pekerja rumah tangga berbayar, pekerja luar industry dan pekerja rumahan.

Karakteristik sektor informal yang berbeda dengan sektor formal menurut Rigon dkk (2020), terjadi karena gagasan utama sektor informal masih dominan di lingkaran kebijakan, yaitu:

a. Informal didasari kegiatan tidak berdasarkan aturan;

b. Informal berbeda dari formal;

c. Informalitas milik orang miskin;

d. Kegiatan informal bersifat lokal, dan kebanyakan berlokasi di daerah informal kota;

e. Perubahan ke sektor informal hanya mempengaruhi kesejahteraan mereka yang bekerja di dalamnya. (Rigon et al., 2020)

Berdasarkan berbagai konsep sektor informal, yang dimaksud pekerja sektor informal dalam paper ini adalah mereka yang bekerja secara mandiri pada unit usaha kecil dengan modal kecil dan teknologi sederhana. Pekerja informal tidak tersentuh perjanjian kerja yang ketat, tidak memiliki jaminan sosial dan kesehatan sehingga rentan terkena dampak resesi ekonomi.

\section{Dampak Era New Normal}

Kemunculan kembali normal baru bersamaan dengan hadirnya konsep society 5.0. Kedua kondisi tersebut membutuhkan korporasi dan konsumen yang paham dan mampu untuk menggunakan teknologi dengan tujuan agar tercipta kualitas hidup yang lebih baik.

Tantangan dunia bisnis di era konektivitas global semakin besar. Tantangan utamanya disebabkan oleh perubahan situasi pasar yang terjadi secara cepat dan acak sehingga 
kondisi masa depan sulit untuk diprediksi. Menurut Lizardo dan Furindo (2020), fenomena lingkungan bisnis saat ini disebut sebagai VUCA ( Volatility, Uncertainty, Complexity dan Ambiguity) yang merujuk pada suatu kondisi kebergejolakan, ketidakpastian, kerumitan dan kegalauan.

Era VUCA menggambarkan situasi bisnis yang mengarah pada ketidakpastian dan mudah berubah sehingga menimbulkan kecemasan. Pengertian VUCA menurut US Army War College (Aribowo \& Wirapraja, 2018)sebagai berikut:

1. Volatility (Bergejolak)

Berbisnis di era kemajuan teknologi pesat, tingkat inovasi yang didasarkan pada perkembangan teknologi, dan perubahan yang terus menerus, mengharuskan pelaku bisnis memiliki kemampuan untuk menguasai teknologi dan memanfaatkannya dalam memenangkan persaingan.

2. Uncertainty (Ketidakpastian)

Situasi yang penuh dengan ketidakpastian membuat kondisi pasar dan industri sulit diprediksi dan dikendalikan. Oleh karena itu diperlukan kemampuan memprediksi perubahan pasar dan pengambilan keputusan yang tepat untuk mengendalikan perubahan.

\section{Complexity (Kerumitan)}

Kondisi lingkungan usaha yang berubah cepat menciptakan kerumitan dalam pengelolaannya. Kerumitan ini menyebabkan pergeseran yang semula hanya fokus pada mengejar profit, saat ini menjadi lebih kompleks dimana karena harus mempertimbangkan banyak faktor agar bisnis dapat bertahan di era persaingan.

\section{Ambiguity (Kegalauan)}

Kondisi bisnis yang ambiguity digambarkan sebagai suatu situasi dimana tidak ada batas antara area bisnis yang satu dengan lainnya atau batasan tersebut mengabur . Dalam situasi seperti ini tidak dapat dipastikan bahwa competitor usaha berasal dari bidang yang sama. Karena dapat terjadi pebisnis yang semula berada di area yang berbeda dapat mengekspansi area bisnis yang sama.

Tantangan bisnis di era normal baru menurut Santosa (2020) dapat berasal dari pelaku usaha, baik sebagai pemasok, pelanggan dan pesaing. Akibat pandemi yang berkepanjangan, berdampak pada kemampuan pasokan bahan baku karena pembatasan interaksi. Bahan baku tertentu stoknya langka karena sebagian digunakan untuk kebutuhan pencegahan persebaran virus. Selain itu penerapan protokol kesehatan dalam proses dan distribusi bahan baku mempengaruhi jumlah pasokan.

Pengusaha sebagai produsen dihadapkan pada permasalahan kegiatan produksi dan distribusi yang terganggu, sehingga kegiatan pemasaran terhambat. Kondisi ini terjadi 


\section{Journal Publicuho}

ISSN2621-1351 (online), ISSN 2685-0729 (print)

Volume 4 Number 2 (May-July), (2021)pp. 248-258

Accredited SINTA SK.NOMOR 28/E/KPT/2019

Open Access at:http://ojs.uho.ac.id/index.php/PUBLICUHO/index

DOI: 10.35817/jpu.v4i2.17705

karena perusahaan menerapkan protokol kesehatan untuk membatasi interaksi dan jaga jarak. Hal ini berdampak pada pengurangan kapasitas produksi.

Tantangan bisnis dapat pula bersumber dari perubahan perilaku konsumen sebagai akibat pandemi Covid-19. Hasil survey Badan Pusat Statistik, pandemi membawa perubahan pada perilaku masyarakat. Perilaku tersebut dapat dikelompokkan ke dalam tiga tahapan, yaitu: sebelum pandemi, fase masa pandemi, dan fase masa transisi. Masa sebelum pandemi antara 15 Februari 2020 hingga 14 Maret 2020, fase masa pandemi antara tanggal 15 Maret 2020 hingga 31 Mei 2020, dan fase transisi atau penerapan era normal baru antara bulan Juni hingga saat ini.(BPS, 2020)

Pada fase masa pandemi perilaku konsumen dipengaruhi faktor sosial yang berkembang saat itu sebagai dampak dari penerapan kebijakan bekerja dari rumah. Terdapat pergeseran aktifitas yaitu meningkatnya aktifitas di rumah dan menurunnya aktifitas di tempat kerja. Berdasarkan hasil survey yang dilakukan oleh Badan Pusat Statistik perubahan aktifitas ini menyebabkan angka aktifitas di rumah meningkat 9,5 persen, Sebagai akibat bekerja dari rumah, aktivitas di tempat kerja menurun 16,5. Persen. (BPS, 2020)

Badan Pusat Statistik juga melaporkan adanya perubahan perilaku konsumen akibat dari pandemic. Penjualan berbasis digital pada masa pandemi melonjak tajam bila disbandingkan dengan penjualan bulan Januari 2020. Pada bulan Maret tercatat 320 persen dari total penjualan berbasis digital pada awal tahun. Peningkatan semakin tinggi terjadi, pada bulan April 2020 tercatat meningkat hingga 480 persen. (BPS, 2020)

Pada bulan Maret penjualan tertinggi ada pada makanan dan minuman, meningkat hingga 570 persen dari penjualan di Januari 2020, dan penjualan terendah adalah produk olahraga yang hanya meningkat 170 persen dari penjualan Januari. Bulan April penjualan tertinggi masih dipegang makanan dan minuman yang melonjak hingga $1070 \%$ dari penjualan di bulan Januari 2020. Penjualan terendah juga masih produk olahraga yang sedikit mengalami peningkatan 210 persen. (BPS, 2020).

Fase masa transisi setelah pemerintah menerapkan era normal baru, aktivitas masyarakat di tempat kerja, tetap mengalami penurunan sebesar 25,7 persen dibandingkan angka aktivitas pada fase sebelum pandemi. Sedangkan aktivitas masyarakat di rumah tetap mengalami peningkatan, karena proses pembelajaran sekolah dan perguruan tinggi masih dilaksanakan secara daring. Sementara itu pembatasan sosial berskala besar masih diterapkan di beberapa wilayah.

\section{Strategi Menghadapi Tantangan di era New Normal}

Penerapan tatanan normal baru bertujuan agar masyarakat dapat beraktifitas, bekerja dan berniaga pada kondisi yang aman dan terhindar dari penularan. Tatanan normal baru tidak hanya diterapkan pada lingkungan keluarga tetapi juga pada semua aspek kehidupan, 
seperti di tempat kerja, pusat perbelanjaan, pusat pelayanan kesehatan, pasar tradisional, transportasi publik dan tempat pariwisata.

Penerapan tatanan normal baru berdampak pada karakteristik lingkungan usaha. Lingkungan usaha di masa pandemi menuntut perubahan pelayanan yang lebih memperhatikan kesehatan, aman, dan meminimalisir kontak secara fisik. Untuk menyiasati hal ini perlu dilakukan modifikasi pada usaha sektor informal. Upaya yang dilakukan harus mengacu pada karakteristik lingkungan usaha yang berkembang saat ini. Salah satu cara adalah memodifikasi produk, misalnya dengan menjual makanan versi beku agar dapat dinikmati konsumen.(Mas'udi, 2020)

Karakteristik lingkungan usaha di masa normal baru adalah lingkungan yang berbasis digital. Bagi pekerja sektor informal yang tidak dapat beradaptasi dengan tuntutan tersebut, cenderung memiliki penghasilan kecil dan konsumen terbatas jangkauannya. Bagi pekerja sektor informal yang dapat memanfaatkan media komunikasi dan media sosial lebih banyak mendapatkan kesempatan menambah pelanggan, karena jangkauan pasar yang luas. Dari hasil survey Insight selama pandemi ada sekitar 54 persen UMKM di Indonesia menggunakan media sosial sebagai media untuk pemasaran.(Alika, 2020).

Menjalin kerjasama dengan pihak-pihak yang dapat membantu memanfaatkan kapasitas dan kapabilitas yang dimiliki. Berdasarkan hasil survey yang dilakukan oleh Badan Pusat Statistik Tahun 2020, penjualan langsung memang menurun, tetapi pada belanja online terjadi peningkatan. Produk yang banyak diminati dan menduduki penjualan tertinggi diantaranya adalah masker kain, suplemen makanan, perawatan tubuh dan perawatan diri. Informasi ini dapat dimanfaatkan oleh penjahit untuk memproduksi pakaian pelindung diri dan masker kain.

Dengan memperhatikan perkembangan lingkungan usaha, maka strategi yang perlu dilakukan pekerja sektor informal adalah sebagai berikut:

a. Memperhatikan faktor kesehatan dan keamanan dengan menerapkan protokol kesehatan

b. Memiliki kemampuan bekerjasama

c. Kemampuan beradaptasi dengan perubahan perilaku konsumen yang bergeser ke arah pembelian berbasis digital

d. Memiliki kemampuan inovasi dan kreatifitas 


\section{Journal Publicuho}

ISSN2621-1351 (online), ISSN 2685-0729 (print)

Volume 4 Number 2 (May-July), (2021)pp. 248-258

Accredited SINTA SK.NOMOR 28/E/KPT/2019

Open Access at:http://ojs.uho.ac.id/index.php/PUBLICUHO/index

DOI: 10.35817/jpu.v4i2.17705

\section{KESIMPULAN}

Pemberlakuan era normal baru merupakan salah satu upaya pemerintah untuk membangkitkan aktivitas perekonomian masyarakat agar tetap produktif dan terhindar dari penularan Covid-19. Namun perkembangan situasi perekonomian yang merupakan imbas dari pandemi berdampak pada situasi bisnis. Setidaknya ada 3 faktor yang mempengaruhi perkembangan situasi bisnis pada era normal baru. Pertama, situasi bisnis yang bergejolak karena perubahan yang terus menerus, situasi yang penuh dengan ketidak pastian yang membuat kondisi pasar sulit untuk dikendalikan. Sehingga menimbulkan kerumitan dalam menjalankan bisnis, dimana bisnis saat ini tidak hanya fokus pada mendapatkan laba, tetapi harus memikirkan strategi untuk bertahan di era yang penuh dengan persaingan. Berbagai situasi tersebut menimbulkan kegalauan bagi pelaku bisnis.

Kedua, penerapan era normal baru berdampak pada pelaku bisnis sebagai pemasok, pelanggan dan pesaing yang menghadapi berbagai keterbatasan sumber daya dan situasi bisnis yang kompleks.

Ketiga, perubahan perilaku konsumen yang lebih berorientasi pada keamanan dalam bertransaksi, berdampak pada perubahan pola belanja yang semula belanja offline, bergeser ke belanja online.

Berdasarkan dampak yang berpengaruh terhadap pekerja sektor informal, untuk dapat bertahan dan memenangkan persaingan, pekerja sektor informal harus melakukan berbagai upaya. Pertama, dalam menjalankan usaha menerapkan protokol kesehatan agar terhindar dari penularan. Kedua, memanfaatkan jaringan kerja sama menggandeng berbagai pihak dengan memanfaatkan sumber daya dan keahlian yang dimiliki. Ketiga, adaptif dan merespon perubahan perilaku konsumen dengan memanfaatkan teknologi. Keempat mengembangkan inovasi dan kreatifitas untuk menghadapi perubahan.

\section{DAFTAR PUSTAKA}

Alika, R. (2020). Survei: 54\% UMKM Pakai Media Sosial untuk Pacu Penjualan saat Pandemi. https://katadata.co.id/ekarina/berita/5efdb7a7bea69/survei-54-umkm-pakai-mediasosial-untuk-pacu-penjualan-saat-pandemi

Aribowo, H., \& Wirapraja, A. (2018). Strategi Inovasi Dalam Rangka Menjaga Keberlanjutan Bisnis Dalam Menghadapi Era Volatility, Uncertainty, Compelxity, Dan Ambiguity (Vuca). Jurnal Ilmu Manajemen Dan Akuntansi Terapan (JIMAT), 9(1), 1-8.

BADAN PUSAT STATISTIK. (2020). TINJAUAN BIG DATA TERHADAP DAMPAK COVID-19. Badan Pusat Statistik.

Bairagya, I. (2014). Liberalization and economic performance of the informal sector: A study of Indian economy. In Liberalization and Economic Performance of the Informal Sector: A Study of Indian Economy. https://doi.org/10.4324/9781315756974 
BPS. (2020). Katalog: 3101028.

Chen, Martha Alter. (2012). The Informal Economy: Definition, Theories and Policies, Woman In Informal Employment Globalizing and Organizing, Working Paper No. 1

Dampaknya, C.-D. A. N., Hak, T., \& Manusia, A. (n.d.). AMNESTY INTERNATIONAL BRIEFING Amnesty International adalah sebuah gerakan global.

ILO. (2020). Krisis COVID-19 dan Sektor Informal: Respons langsung dan tantangan kebijakan. 1-36. https://www.ilo.org/wcmsp5/groups/public/---asia/---ro-bangkok/---ilojakarta/documents/publication/wcms_744424.pdf

KBBI. (2016). Kamus Besar Bahasa Indonesia ( KBBI ). In Kementerian Pendidikan dan Budaya.

Kuncara, Tommy, dkk. (2020). Prediksi Ekonomi Indonesia Pasca Covid-19, C.V. Jakad Media Publishing.

Lizardo, Jimmy, Furindo Asnan. (2020). Strategi Co-Digination Menghadapi Kompetisi Digital : Membangun Daya Saing Perusahaan di Industri Media Luar Ruang, Scopindo, Media Pustaka, Surabaya.

Mas'udi, W. dan P. S. W. (2020). New Normal: Perubahan Sosial Ekonomi dan Politik Akibat COVID-19. In New Normal: Perubahan Sosial Ekonomi dan Politik Akibat COVID-19.

Novika, S. (2020). Sederet Alasan Pemerintah Terapkan New Normal. In detikFinance (p. 1). https://finance.detik.com/berita-ekonomi-bisnis/d-5039532/sederet-alasan-pemerintahterapkan-new-normal

Nugroho, Lucky, dkk. (2020). Indonesia Maju dan Bangkit, Qiara Media, Pasuruan.

Putra, Chandra Andika, Fitriani, Sarah. (2020). Seri 2: Fakta \& Mitos Covid-19: Informasi yang harus diketahui seputas Coronavirus, Guepedia, Jakarta

Rahayu, Teguh, Sinambela, Marzuki.(2020). Air Mata Covid-19 Dalam Bencana Gempabumi dan Tsunami, Yayasan Kita Menulis,

Rahman, M. A., Kusuma, A. Z. D., \& Arfyanto, H. (2020). Situasi ketenagakerjaan di lapangan usaha yang terdampak pandemi covid-19. 1, 1-4.

Rigon, A., Walker, J., \& Koroma, B. (2020). Beyond formal and informal: Understanding urban informalities from Freetown. Cities. https://doi.org/10.1016/j.cities.2020.102848

Santoso, Dwi H. (2020). Marketing di New Normal : Strategi dan Taktik Melewati Badai, Insan Mandiri Cendikia, Jakarta

Todaro, M. P. (2008). Pembangunan Ekonomi (Jilid 1) (Edisi 9). In Edisi Kesembilan terjemahan oleh Haris Munandar dan Puji AL Jakarta: Erlangga.

Yazid, E. K. (2020). Tantangan dan Adaptasi Lapangan Kerja di Era Pandemi COVID-19. April, $1-5$.

Yustika, Ahmad. Erani.(2011). Dari Krisis ke Krisis:Potret Terkini Perekonomian Nasional, UB Press, Malang.

Wantrianthos, dkk. (2020). Belajar dari Covid-19 : Perspektif Teknologi dan Pertanian, Yayasan Kita Menulis. 